\title{
Identification of New Source of Resistance to Powdery Mildew of Indian Mustard and Studying Its Inheritance
}

\author{
Joghee Nanjundan (iD ${ }^{1 *}$, Channappa Manjunatha ${ }^{1}$, Jalli Radhamani ${ }^{2}$, Ajay Kumar Thakur ${ }^{3}$, Rashmi Yadav ${ }^{2}$, \\ Arun Kumar ${ }^{3}$, Mohan Lal Meena ${ }^{1}$, Rishi Kumar Tyagi ${ }^{2}$, Devender Kumar Yadava ${ }^{4}$, and Dhiraj Singh ${ }^{3}$ \\ ${ }^{1}$ ICAR-Indian Agricultural Research Institute, Regional Station, Wellington, The Nilgiris, Tamil Nadu 643 231, India \\ ${ }^{2}$ ICAR-National Bureau of Plant Genetic Resources, New Delhi 110 012, India \\ ${ }^{3}$ ICAR-Directorate of Rapeseed-Mustard Research, Bharatpur, Rajasthan 321 303, India \\ ${ }^{4}$ ICAR-Indian Agricultural Research Institute, New Delhi 110 012, India
}

(Received on July 25, 2019; Revised on November 20, 2019; Accepted on February 18, 2020)

Powdery mildew of Indian mustard (Brassica juncea), caused by Erysiphe cruciferarum, is emerging as major problem in India. All the Indian mustard cultivars presently grown in India are highly susceptible to powdery mildew and so far no resistance source has been reported. In this study, with an aim to identify resistant source, 1,020 Indian mustard accessions were evaluated against $E$. cruciferarum PMN isolate, at Wellington, The Nilgiris, Tamil Nadu, India under natural hot spot conditions. The study identified one accession (RDV 29) with complete resistance against $E$. cruciferarum PMN isolate for the first time, which was consistent in five independent evaluations. Genetic analysis of $F_{1}, F_{2}$ and backcross populations obtained from the cross RSEJ 775 (highly susceptible) $\times$ RDV 29 (highly resistant) for two season revealed that the resistance is governed by two genes with semi-dominant and gene dosage effect. Further, a new disease rating system using six scales $(0,1,2,3,4$, and 5$)$ has also been proposed in this study to score powdery mildew based on progress of fungal growth in different plant parts of the $F_{2}$ population.

\footnotetext{
*Corresponding author.

Phone) +91-423-2234796, FAX) +91-0423-2230463

E-mail) agrinanju@gmail.com

ORCID

Joghee Nanjundan

https://orcid.org/0000-0001-6254-7341

(c) This is an Open Access article distributed under the terms of the Creative Commons Attribution Non-Commercial License (http:// creativecommons.org/licenses/by-nc/4.0) which permits unrestricted noncommercial use, distribution, and reproduction in any medium, provided the original work is properly cited.
}

Articles can be freely viewed online at www.ppjonline.org.
The outcome of this study viz. newly identified powdery mildew-resistant Indian mustard accession (RDV 29), information on inheritance of resistance and the newly developed disease rating scale will provide the base for development of powdery mildew-resistant cultivars of Indian mustard.

Keywords : Erysiphe cruciferarum, Indian mustard, inheritance, powdery mildew, resistance

Handling Editor : Inhwa Yeam

India is the fifth largest vegetable oil economy in the world next to the United States, China, Brazil, and Argentina accounting for $5.8 \%$ vegetable oil production, $11.2 \%$ of world oil import and $9.3 \%$ of the world edible oil consumption (Anonymous, 2015). Despite having considerable area under cultivation of oilseed crops (26.20 mha), India is a major importer of edible oil and imports edible oil of worth $>$ Rs. 0.73 trillion annually (Ministry of Agriculture and Farmers Welfare, Government of India, 2017). Among various oilseed crops, oilseed Brassicas, particularly Brassica juncea (L.) Czern. \& Coss (Indian mustard) represents the most important and widely cultivated species occupying $>80 \%$ of rapeseed-mustard acreage (6.02 mha). However, the average productivity of Indian mustard in India is very low $(1,324 \mathrm{~kg} / \mathrm{ha})$, which is mainly attributed to yield stagnation in new varieties and increasing pressure posed by various biotic and abiotic stresses. Among various biotic stresses, particularly the fungal diseases, powdery mildew of Indian mustard, caused by Erysiphe cruciferarum Opiz. Ex. Junell., has been reported to cause significant yield losses, sporadically, depending on the prevailing agro- 
ecological conditions. This disease was once considered to be of minor importance, but in the recent years, it became widespread throughout the mustard growing regions of India particularly in the states like Uttar Pradesh, Rajasthan, Jammu \& Kashmir, Haryana and Gujarat (Mohitkar et al., 2012) and in other non-traditional mustard growing areas such as Maharashtra, Karnataka and Andhra Pradesh. All the Indian mustard cultivars currently being cultivated in different states of India are highly susceptible to this disease. This fungus can infect any above-ground plant parts and can cause heavy yield losses by reducing plant growth and consequently, the quantity and quality of seeds (Dange et al., 2002; Kumar and Saharan, 2002; Meena et al., 2014; Saharan and Kaushik, 1981). In the states of Gujarat and Maharashtra, where the powdery mildew occurs in severe form, the estimated losses in seed yield, oil, protein and test weight due to E. cruciferarum infection was $22.50,7.26$, 21.74 , and $21.52 \%$, respectively (Kanzaria, 2012).

Host plant resistance (R) genes have been widely exploited in crop breeding to develop disease-resistant cultivars for minimizing crop yield losses due to various pathogens. In India, earlier attempts to identify resistant source to powdery mildew of Indian mustard went into fiascos as all the $B$. juncea genotypes evaluated were found to be highly susceptible to this dreaded pathogen and whatever the resistant sources reported belonged to other related species and allied genera such as B. carinata, B. napus, B. alboglabra, B. japonica, Sinapis alba, Eruca sativa (Kumar et al., 2002; Mohitkar et al., 2012; Narain and Siddiqui, 1965); Arabidopsis thaliana (Xiao et al., 2001); B. rapa, B. oleracea, and B. napus (Li et al., 2016), with no reports available about its resistance in $B$. juncea, which is an important oil yielding species in Indian context. In the absence of any information pertaining to source of resistance to powdery mildew in Indian mustard and its trait genetics, no systematic research work could be undertaken to combat this disease.

Keeping in view the economic importance of powdery mildew disease in Indian mustard, research initiatives have begun at ICAR-Indian Agricultural Research Institute, Regional Station, Wellington, which is a hot spot for this disease inter alia many other crop diseases (Nanjundan et al., 2017). In this paper, we are reporting for the first time the identification of a highly resistant source for powdery mildew in Indian mustard obtained after rigorous screening of Indian mustard germplasm under natural ephiphytotic conditions, standardization of powdery mildew disease scoring system and its inheritance pattern for future use in resistance breeding programmes.

\section{Materials and Methods}

Plant material. Plant material comprised of a total of 1,020 Indian mustard germplasm accessions with diverse genetic background, which included core set (146 accessions), yield-component trait specific set (135 accessions) procured from ICAR-Directorate of Rapeseed-Mustard Research, Bharatpur, Rajasthan, India; and another set of 739 accessions from National Gene Bank (NGB), ICARNational Bureau of Plant Genetic Resources, New Delhi and four susceptible checks (popular cultivars) viz. 'NRCDR 02', 'NCRDR 601', 'Giriraj', and 'Rohini'. All these accessions were true-to-type with highly uniform plant type due to continuous self pollination.

Disease hotspot and experimental layout. ICAR-IARI, Regional Station, Wellington (The Nilgiris, Tamil Nadu, India), with its unique location and climatic conditions (latitude, $11^{\circ} \mathrm{N}$; longitude, $77^{\circ} \mathrm{E}$; altitude, $1,850 \mathrm{~m}$; average temperature, $5-25^{\circ} \mathrm{C}$; annual rainfall, $1,500 \mathrm{~mm}$ ) is a hotspot for powdery mildew of Indian mustard. Powdery mildew pathogen survives at Wellington round the year through the agencies of self-sown/stray plants/green bridge and therefore, infection occurs naturally in susceptible cultivars. E. cruciferarum isolate prevalent at the Wellington is designated as PMN (powdery mildew Nilgiri) to reflect its origin. Screening was conducted in augmented block design (ABD) by repeating the four susceptible checks in every block. Each accession was sown in single row of $3 \mathrm{~m}$ length with row-to-row and plant-to-plant spacing of $30 \mathrm{~cm}$ and $10 \mathrm{~cm}$, respectively. Recommended cultural practices (NPK equivalent to $60: 30: 30 \mathrm{~kg} / \mathrm{ha}$; irrigation at 10-day interval; frequent hand weeding, etc.), except spraying of fungicides and insecticides, were followed till the crop was harvested. The soil type of the experimental plot was sandy loam to sandy clay loam with following basic properties; organic matter $0.56-0.78 \%$, EC $0.24-0.52 \mathrm{dS} / \mathrm{m}$ and $\mathrm{pH}$ 4.4-5.5.

Resistance to powdery mildew during first year of screening. Utilizing the hot spot conditions, all the 1,020 accessions and four check varieties mentioned earlier were planted and evaluated for powdery mildew resistance, during kharif 2016. The disease scoring was carried at the siliquae filling stage of the crop (i.e., 80-90 days after sowing), the stage at which the incidence of powdery mildew is maximum and reported to cause significant yield losses. The following four visual categorical scales were used to rate disease reaction: HR, 'highly resistant', no fungal colo- 


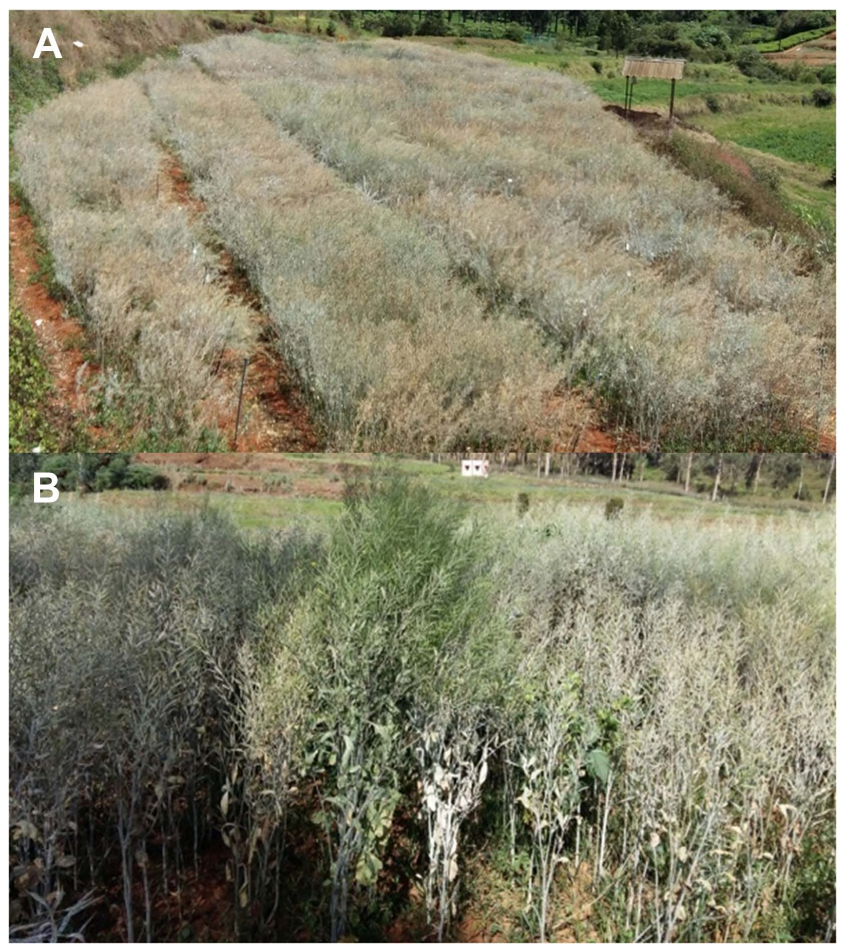

Fig. 1. Evaluation for powdery mildew resistance under hot spot conditions at Wellington. (A) Experimental fields showing mustard field with powdery mildew incidence. (B) Identified powdery mildew-resistant Indian mustard accession (RDV 29) in central row.

nies seen throughout the plant; MR, 'partially resistant', a few colonies with sparse sporulation visible on the leaves and stem; MS, 'moderately susceptible', more colonies with profuse sporulation visible on the leaves, stem, and branches; and HS, 'highly susceptible', abundant colonies with profuse sporulation visible covering entire plant parts i.e., leaves, stem, branches, and siliquae. While the entire field was covered with thick whitish mycelial growth of fungi (Fig. 1A), only 12 accessions were identified with some degree of resistance and classified as 'partially resistant' and one accession, named RDV 29, exhibited high degree of resistance (Fig. 1B) classified as 'highly resistant'. Only the 24 accessions (13 'resistant' and 11 'susceptible' accessions) were carried to the next step of evaluation.

Re-evaluation of selective 24 accessions. The selective 24 accessions mentioned in (Table 1) and four check varieties viz. NRCDR 02, NCRDR 601, Giriraj and Rohini were re-evaluated for powdery mildew resistance during the next crop season i.e., rabi-2016-17. The experiment was conducted in $\mathrm{ABD}$ in which the accessions and the four checks were sown in four rows of $3 \mathrm{~m}$ length. The plant spacing, cultural practices, and the disease scoring methods followed were same as in the first year of experiment. One infector/spreader row (RSEJ 775, the susceptible check) was maintained at intervals of every 5 th accession to ensure that plants were continually exposed to inoculums. Further, four accessions which included two 'resistant' (RDV 29 and KLM 4) and two 'susceptible' (RSEJ 775 and RH 0704) were repeatedly evaluated by sowing them at three different dates (with a minimum of 4-week interval between each sowing), in addition to the two-season evaluation mentioned earlier, to test the consistency of disease reaction. After evaluation in five consecutive plantings, two accessions, i.e., RDV 29 (with the highest level of resistant) and RSEJ 775 (with the highest level of susceptibility) with consistent results were sorted out to make crosses and to study the inheritance of powdery mildew resistance.

Inheritance pattern of powdery mildew resistance. The highly resistant $B$. juncea accession RDV 29 was crossed (as male parent) with the highly susceptible $B$. juneca accession RSEJ 775 (as female parent) to get $F_{1}$ population. The $F_{1}$ plants were selfed to get $F_{2}$ seeds and test cross $\left(F_{1} \times\right.$ RSEJ 775) was also performed to evaluate the various inheritance patterns determined from analyzing the $\mathrm{F}_{2}$ segregation data. In the field, 40 plants of susceptible parents (RSEJ 775), 40 plants of resistant parent (RDV 29), $35 \mathrm{~F}_{1}$ (RSEJ $775 \times$ RDV 29) plants, $346 \mathrm{~F}_{2}$ individuals, 32 susceptible back cross progenies $\left(\mathrm{F}_{1} \times \mathrm{RSEJ} 775\right)$ and 28 resistant back cross progenies $\left(F_{1} \times\right.$ RDV 29) were evaluated against the powdery mildew disease under hot spot conditions with heavy load of powdery mildew inoculums, during rabi-2017-18. Another $\mathrm{F}_{2}$ population with 275 plants obtained by crossing RDV $29 \times$ RSEJ 775 (reciprocal cross) was also evaluated to detect the presence of maternal effect, if any, in the inheritance of powdery mildew resistance. During kharif 2018, the field evaluation was repeated wherein 38 plants of susceptible parents (RSEJ 775), 42 plants of resistant parent (RDV 29), $41 \mathrm{~F}_{1}$ (RSEJ $775 \times$ RDV 29) plants, $289 \mathrm{~F}_{2}$ individuals, 102 susceptible back cross progenies $\left(F_{1} \times\right.$ RSEJ 775) and 192 resistant back cross progenies $\left(F_{1} \times R D V 29\right)$ were evaluated against the powdery mildew disease under similar hot spot conditions.

Development of new scales for disease scoring. Due to the lack of information about the innate variability present in the Indian mustard germplasm for powdery mildew resistance/susceptibility, so far, no standard disease scale had been developed to score this important disease. Hence, in this study an attempt has been made to develop a new system of disease scoring (using 6 scales, i.e., 0, 1, 2, 3, 4 and 5 ) for powdery mildew of Indian mustard mainly by com- 
Table 1. Reaction of 24 Indian mustard accessions and four check varieties to Erysiphe cruciferarum during kharif 2016 and rabi 201617

\begin{tabular}{|c|c|c|c|c|c|c|}
\hline \multirow{2}{*}{$\begin{array}{l}\text { Sr. } \\
\text { No. }\end{array}$} & \multirow{2}{*}{$\begin{array}{l}\text { Name of } \\
\text { accession }\end{array}$} & \multirow{2}{*}{$\begin{array}{l}\text { National } \\
\text { identity }\end{array}$} & \multirow{2}{*}{$\begin{array}{c}\text { Country and state of } \\
\text { origin }\end{array}$} & \multirow{2}{*}{ Sourced from } & \multicolumn{2}{|c|}{ Reaction to E. cruciferarum } \\
\hline & & & & & Kharif 2016 & Rabi 2016-17 \\
\hline 1 & PBR 2004-06 & IC 511487 & India, Punjab & ICAR-DRMR, Bharatpur, Rajasthan & Partially resistant & Partially resistant \\
\hline 2 & EC 511481 & EC 511481 & Canada & NGB, ICAR-NBPGR, New Delhi & Partially resistant & Partially resistant \\
\hline 3 & NBPG 29 & - & India & NGB, ICAR-NBPGR, New Delhi & Partially resistant & Partially resistant \\
\hline 4 & SKACV 09-62 & IC 571685 & India, Karnataka & NGB, ICAR-NBPGR, New Delhi & Partially resistant & Partially resistant \\
\hline 5 & sel 68 & IC 511485 & India, Karnataka & ICAR-DRMR, Bharatpur, Rajasthan & Partially resistant & Partially resistant \\
\hline 6 & NRCDR 02 & IC 511526 & India, Rajasthan & ICAR-DRMR, Bharatpur, Rajasthan & $\begin{array}{l}\text { Moderately } \\
\text { susceptible }\end{array}$ & $\begin{array}{l}\text { Moderately } \\
\text { susceptible }\end{array}$ \\
\hline 7 & NRCHB 101 & IC 559588 & India, Rajasthan & ICAR-DRMR, Bharatpur, Rajasthan & Partially resistant & Partially resistant \\
\hline 8 & SN 117 & IC 426404 & India, Andhra Pradesh & ICAR-DRMR, Bharatpur, Rajasthan & Partially resistant & Partially resistant \\
\hline 9 & KLM 4 & - & India, Punjab & ICAR-DRMR, Bharatpur, Rajasthan & Partially resistant & Partially resistant \\
\hline 10 & EC 511735 & EC 511735 & Canada & ICAR-DRMR, Bharatpur, Rajasthan & Highly susceptible & $\begin{array}{l}\text { Moderately } \\
\text { susceptible }\end{array}$ \\
\hline 11 & SKCV 09-38 & IC 571661 & India, Karnataka & NGB, ICAR-NBPGR, New Delhi & Partially resistant & Partially resistant \\
\hline 12 & NRCDR 601 & IC 567221 & India, Rajasthan & ICAR-DRMR, Bharatpur, Rajasthan & $\begin{array}{l}\text { Moderately } \\
\text { susceptible }\end{array}$ & $\begin{array}{l}\text { Moderately } \\
\text { susceptible }\end{array}$ \\
\hline 13 & KLM 145 & IC 511527 & India, Punjab & ICAR-DRMR, Bharatpur, Rajasthan & Partially resistant & Partially resistant \\
\hline 14 & RSEJ 999B & EC 0765266 & United Kingdom & & Highly susceptible & $\begin{array}{l}\text { Moderately } \\
\text { susceptible }\end{array}$ \\
\hline 15 & RSEJ 1014A & EC 07 & & ICAR-DRMR, Bharatpur, Rajasthan & Partially $\mathrm{r}$ & Partially resistant \\
\hline 16 & RESJ 1464 & EC 0765447 & United Kingdom & NGB, ICAR & Partially resistant & Partially resistant \\
\hline 17 & RSEJ $1014 C$ & EC 0765304 & United Kingdom & NGB, ICAR & Highly susceptible & $\begin{array}{l}\text { Moderately } \\
\text { susceptible }\end{array}$ \\
\hline 18 & RDV 29 & IC 589658 & India, Karnataka & NGB, ICAR-NBPGR, New Delhi & Highly resistant & Highly resistant \\
\hline 19 & Giriraj & IC 597693 & India, Rajasthan & ICAR-DRMR, Bharatpur, Rajasthan & $\begin{array}{l}\text { Moderately } \\
\text { susceptible }\end{array}$ & $\begin{array}{l}\text { Moderately } \\
\text { susceptible }\end{array}$ \\
\hline 20 & NE 19 & IC 522329 & India, Assam & NGB, ICAR-NBPGR, New Delhi & Highly susceptible & $\begin{array}{l}\text { Moderately } \\
\text { susceptible }\end{array}$ \\
\hline 21 & SN 55 & IC 426343 & India, Andhra Pradesh & NGB, ICAR-NBPGR, New Delhi & Highly susceptible & Highly susceptible \\
\hline 22 & Rohini & - & India, Uttar Pradesh & ICAR-DRMR, Bharatpur, Rajasthan & $\begin{array}{l}\text { Moderately } \\
\text { susceptible }\end{array}$ & $\begin{array}{l}\text { Moderately } \\
\text { susceptible }\end{array}$ \\
\hline 23 & RH 0704 & - & India, Haryana & ICAR-DRMR, Bharatpur, Rajasthan & Highly susceptible & Highly susceptible \\
\hline 24 & RSEJ 775 & EC 0765098 & United Kingdom & NGB, ICAR-NBPGR, New Delhi & Highly susceptible & Highly susceptible \\
\hline 25 & RESJ 1538C & EC 0765655 & United Kingdom & ICAR-DRMR, Bharatpur, Rajasthan & Highly susceptible & $\begin{array}{l}\text { Moderately } \\
\text { susceptible }\end{array}$ \\
\hline 26 & RESJ 1573 & EC 0765784 & United Kingdom & ICAR-DRMR, Bharatpur, Rajasthan & Highly susceptible & Highly susceptible \\
\hline 27 & RESJ 1636E & EC 0766032 & United Kingdom & ICAR-DRMR, Bharatpur, Rajasthan & Highly susceptible & $\begin{array}{l}\text { Moderately } \\
\text { susceptible }\end{array}$ \\
\hline 28 & RESJ 1647D & EC 0766087 & United Kingdom & ICAR-DRMR, Bharatpur, Rajasthan & Highly susceptible & Highly susceptible \\
\hline
\end{tabular}

ICAR-DRMR, Indian Council of Agricultural Research-Directorate of Rapeseed-Mustard Research; NGB, National Gene Bank; ICAR-NBPGR, Indian Council of Agricultural Research-National Bureau of Plant Genetic Resources.

paring the extent of fungal growth observed on the fully susceptible RSEJ 775, fully resistant RDV 29, intermediate $\mathrm{F}_{1}$ individuals and the range of disease symptoms observed in the $\mathrm{F}_{2}$ population at 80-90 DAS. Percent Disease Index (PDI) was calculated following the formula: PDI $=[\Sigma$ numerical rating/(number of samples scored $\times$ maximum 
Table 2. Newly developed disease rating scales, corresponding disease severity index and assigned phenotypic class for powdery mildew disease of Indian mustard

\begin{tabular}{|c|c|c|c|}
\hline $\begin{array}{l}\text { Disease } \\
\text { scale }\end{array}$ & $\begin{array}{l}\text { Percent Disease } \\
\text { Index }\end{array}$ & Description of the symptoms & Assigned phenotype \\
\hline 0 & No infection & Healthy (i.e., no disease symptoms on the plant) & Highly resistant \\
\hline 1 & 1 to 20 & $\begin{array}{l}\text { From few whitish specks on leaf to entire leaf area covered with whitish fungal } \\
\text { growth }\end{array}$ & Resistant \\
\hline 2 & 21 to 40 & Entire area of leaf and stem covered with whitish fungal growth & Partially resistant \\
\hline 3 & 41 to 60 & Entire area of leaf, stem and primary branch(es) covered with whitish fungal growth & Moderately susceptible \\
\hline 4 & 61 to 80 & $\begin{array}{l}\text { Entire area of leaf, stem, primary branches and secondary branch(es) covered with } \\
\text { whitish growth }\end{array}$ & Susceptible \\
\hline 5 & 81 to 100 & $\begin{array}{l}\text { Entire area of leaf, stem, primary branches, secondary branches and siliquae covered } \\
\text { with whitish growth (i.e., entire plant covered with whitish fungal growth) }\end{array}$ & Highly susceptible \\
\hline
\end{tabular}

score $\times$ 100] (Wheeler, 1969). The PDI was calculated based on two independent disease scorings in individual plants of segregating generations with 10 days gap between the observations. Grouping of plants into distinct phenotypic classes (highly resistant; resistant; partially resistant; moderately susceptible; susceptible and highly susceptible) was done based on disease severity (PDI) as mentioned in Table 2.

Statistical analysis. The statistical significance of the inheritance pattern was tested by chi-square test (Snedecor and Cochran, 1967). Two $F_{2}$ populations (which were derived from direct cross and reciprocal cross) and two back cross population were tested in the rabi 2017-18 whereas, one $\mathrm{F}_{2}$ populations (which was derived from direct cross) and two back cross population were tested in the kharif 2018.

\section{Results}

Screening for powdery mildew resistance. The distribution of 1,020 Indian mustard accessions into four phenotypic classes based on their reaction to powdery mildew caused by E. cruciferarum is presented in (Fig. 2). A total of 996 accessions were classified as 'moderately susceptible' exhibiting heavy infection on leaves, stem, and branches and 11 entries were classified as 'highly susceptible', wherein all the plant parts (leaves, stem, branches, and siliquae) were covered with larger colonies of E. cruciferarum. 'Partially resistant' reaction was expressed by 12 accessions with very less disease observed only on leaves and stem and 'highly resistant' reaction was expressed by only one accession, RDV 29, with no pathogen growth on entire plant surface.

The disease reaction pattern of 24 selective accessions

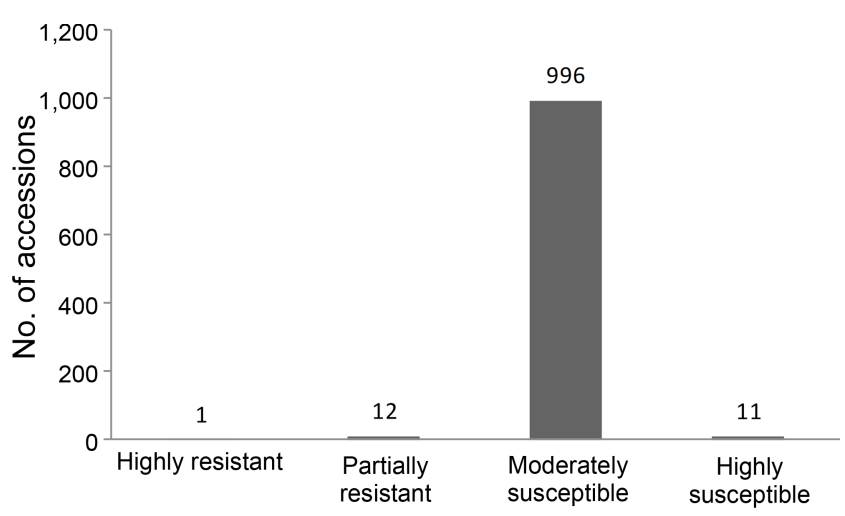

Fig. 2. Distribution of 1,020 Indian mustard accessions into four categories based on their reaction against powdery mildew disease at Wellington.

(one highly resistant, 12 partially resistant, and 11 highly susceptible) and four check varieties which were re-evaluated for two consecutive seasons are presented in Table 1. All the accessions expressed similar kind of resistant/ susceptible reaction in both the seasons except in few accessions viz., EC 511735, RSEJ 999B, RSEJ 1014C, NE 19, RESJ $1538 \mathrm{C}$, and RESJ 1636E, where the reaction was varying between 'highly susceptible' and 'moderately susceptible' in first and second season, respectively. Of particular interest in the field evaluation was the accession RDV 29 which was the most resistant with no incidence of powdery mildew and categorized as 'highly resistant' during both the seasons. Twelve accessions viz. PBR 2004-06, EC 511481, NBPG 29, SKACV 09-62, sel 68, NRCHB 101, SN 117, KLM 4, SKCV 09-38, KLM 145, RSEJ 1014A, and RESJ 1464 developed very less disease confined to leaves, stem and therefore categorized as 'partially resistant' during both the seasons. The 'highly susceptible' accessions SN 55, RH 0704, RSEJ 775, RESJ 1573, and 
RESJ 1647D produced severe incidence on leaves, main stem, branches and siliquae covering the enitre plant surface. All the four check varieties (NRCDR 02, NCRDR 601, Giriraj and Rohini) were categorized as 'moderately susceptible'. Consistent results were observed for four accessions viz., RDV 29 ('highly resistant'), KLM 4 (partially resistant), RH 0704 and RSEJ 775 ('highly susceptible') which were evaluated five times, consecutively, with different dates of sowing (data not shown). Finally, the 'highly resistant' (RDV 29) and 'highly susceptible' (RSEJ 775) among all the accessions were shortlisted and crossed (RSEJ $775 \times$ RDV 29) to study the inheritance pattern.

Development of new scales for disease scoring. Since the growth of E. cruciferarum is superficial, disease symptoms can be documented easily by visual inspection. Powdery mildew first appeared on the upper surface in the lower most (oldest) leaves as small ( 1 to $2 \mathrm{~cm}$ diameter), scattered, white almost circular colonies which coalesced as the colonies grew further, eventually covering the entire leaf surface, stem, primary, secondary branches, and siliquae, progressively. Previous studies (Kaur et al., 2008; Kim et al., 2013; Tam et al., 2016) were also reported similar kind of progress of the powdery mildew pathogen E. cruciferarum, which first appears in leaves and then covers the entire plant of Indian mustard. In the present study, the $\mathrm{F}_{2}$ population exhibited a wide range of disease scores, during both the seasons, i.e., rabi 2017-18 and kharif 2018, with PDI ranges of 0 to $100 \%$ that made it difficult to deduce the genotypes of individuals based on 4 or 5 scales systems de- veloped in previous studies (Adam and Somerville, 1996; Kumar and Saharan, 2002; Mehta et al., 2005; Mohitkar et al., 2012) which taken into account the disease symptom only in leaves. Thus, a new disease scoring system using 0 to 5 scales $(0,1,2,3,4$, and 5$)$ based on the progress of the pathogen growth in different plant parts (leaves, stem, branches, and siliquae) has been developed in this study (Table 2). A score of 0 indicated that 'healthy' (i.e., no disease symptoms on the plant) and score of 1 indicated "from few whitish specks on leaf to entire leaf area covered with whitish fungal growth." An intermediate density of fungal growth was scored as 2, 3, 4 based on the extent of fungal growth over the stem, primary branches, and secondary branches, respectively and a highest score of 5 indicated that "entire area of leaf, stem, primary branches, secondary branches and siliquae or entire plant covered with whitish fungal growth" (i.e., fully compatible interaction). In $\mathrm{F}_{2}$ population, roughly one in 16 individuals exhibited the same disease score as the 'highly susceptible' parent RSEJ 775 and another one in 16 individulas exhibited the same disease score as the 'highly resistant' parent RDV 29, during both the seasons, i.e., rabi 2017-18 and kharif 2018. The disease scores of majority of individuals were distinct from either parent. The $\mathrm{F}_{2}$ variability was scored first based on 0 to 5 scale and then PDI values were computed to group the plants into six phenotypic classes as described in Table 2.

Inheritance of resistance against $\boldsymbol{E}$. cruciferarum. The grouping of $F_{1}, F_{2}$ and back cross progeny plants into six

Table 3. Analysis of inheritance pattern of powdery mildew disease resistance in Indian mustard cross RSEJ $775 \times$ RDV 29 during the two seasons, i.e., rabi 2017-18 and kharif 2018

\begin{tabular}{|c|c|c|c|c|c|c|c|c|c|c|}
\hline \multirow[b]{2}{*}{ Generation } & \multirow[b]{2}{*}{ Year } & \multicolumn{6}{|c|}{ Observed number of plants ${ }^{\mathrm{a}}$} & \multirow{2}{*}{$\begin{array}{l}\text { Chi- } \\
\text { square } \\
\text { value }\end{array}$} & \multirow[b]{2}{*}{$P$-value } & \multirow[b]{2}{*}{ Remark } \\
\hline & & $\begin{array}{l}\text { Highly } \\
\text { resistant }\end{array}$ & Resistant & $\begin{array}{l}\text { Partially } \\
\text { resistant }\end{array}$ & $\begin{array}{l}\text { Moderately } \\
\text { susceptible }\end{array}$ & Susceptible & $\begin{array}{c}\text { Highly } \\
\text { susceptible }\end{array}$ & & & \\
\hline $\mathrm{F}_{1}$ (RSEJ 775 & Rabi 2017-18 & - & - & $35(35)$ & - & - & - & - & - & Partially resistant \\
\hline × RDV 29) & Kharif 2018 & - & - & $41(41)$ & - & - & - & - & - & Partially resistant \\
\hline $\mathrm{F}_{2}(\mathrm{RSEJ} 775$ & Rabi 2017-18 & \multicolumn{3}{|c|}{$201(195)$} & \multicolumn{2}{|c|}{$128(130)$} & $17(21)$ & 1.22 & $0.748^{*}$ & Good fit for $9: 6: 1$ \\
\hline × RDV 29) & Kharif 2018 & \multicolumn{3}{|c|}{$157(163)$} & \multicolumn{2}{|c|}{$115(108)$} & $17(18)$ & 0.73 & $0.866^{*}$ & Good fit for $9: 6: 1$ \\
\hline $\begin{array}{l}\mathrm{F}_{2}(\mathrm{RDV} 29 \\
\times \text { RSEJ } 775)-\end{array}$ & Rabi 2017-18 & \multicolumn{3}{|c|}{$162(154)$} & \multicolumn{2}{|c|}{$95(103)$} & $18(17)$ & 1.02 & $0.796^{*}$ & Good fit for $9: 6: 1$ \\
\hline \multicolumn{11}{|c|}{ Reciprocal cross } \\
\hline $\mathrm{BC}_{1} \mathrm{P}_{1}$ & Rabi 2017-18 & - & - & $9(8)$ & - & $14(16)$ & $9(8)$ & 0.5 & $0.919^{*}$ & Good fit for $1: 2: 1$ \\
\hline$\left(\mathrm{F}_{1} \times\right.$ RSEJ 775) & Kharif 2018 & - & - & $28(25)$ & - & $53(51)$ & $21(25)$ & 1.08 & $0.782^{*}$ & Good fit for $1: 2: 1$ \\
\hline $\mathrm{BC}_{1} \mathrm{P}_{2}$ & Rabi 2017-18 & $8(7)$ & $12(14)$ & $8(7)$ & - & - & - & - & - & All resistant \\
\hline$\left(\mathrm{F}_{1} \times \mathrm{RDV} 29\right)$ & Kharif 2018 & $45(48)$ & $103(96)$ & $44(48)$ & - & - & - & - & - & All resistant \\
\hline
\end{tabular}

*Indicates model analysis accepted $(P \geq 0.05)$.

${ }^{a}$ Expected number of plants are in parentheses. 


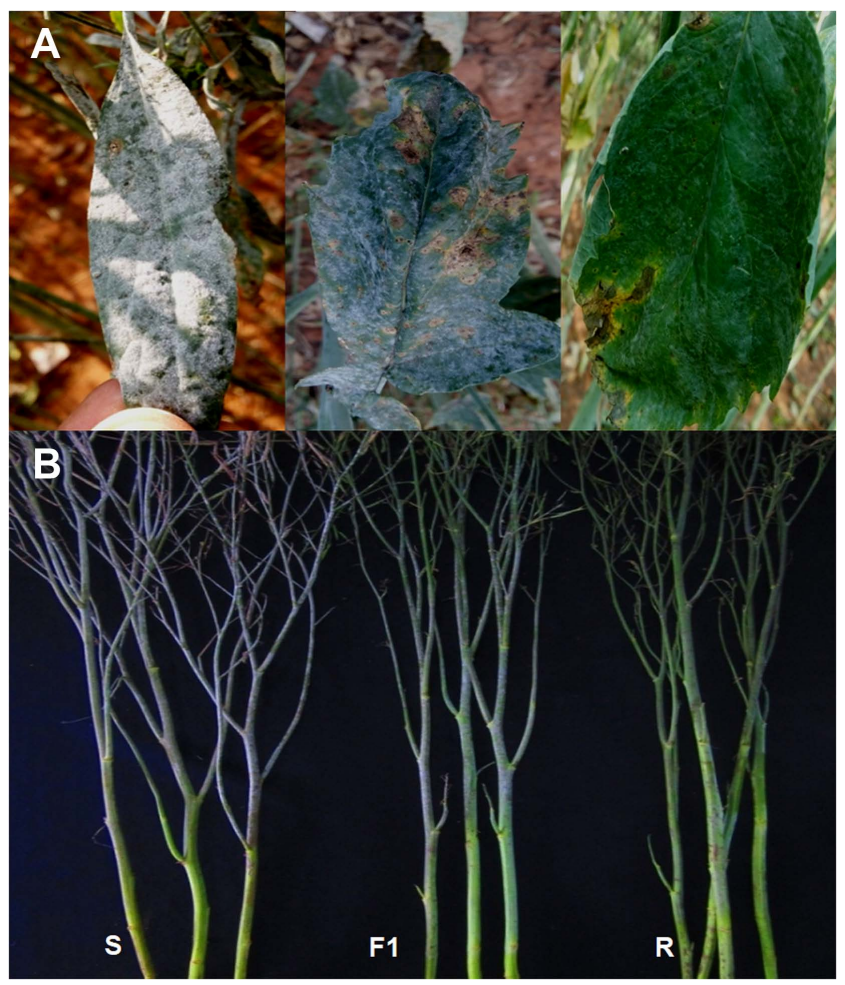

Fig. 3. Powdery mildew symptoms in parents ( $\mathrm{S}$, susceptible parent [RSEJ 775]; R, resistant parent [RDV 29]) and $F_{1}$. (A) On leaf. (B) On stem and branches.

disease reaction phenotypes during two seasons, i.e., rabi 2017-18 and kharif 2018 is presented in Table 3. The $F_{1}$ plants from the cross RSEJ $775 \times$ RDV 29 exhibited intermediate disease reaction (PDI $=21$ to 40 ), as indicated by reduced fungal growth with a limited number of infection sites on leaves and main stem when compared with the susceptible parent, RSEJ 775 (Fig. 3A and B). In $\mathrm{F}_{1}$ plants, the sporadic growth of fungus was not reaching the branches and siliquae unlike in susceptible RSEJ 775 where entire plant (including all the primary, secondary branches and siliquae) were completely covered with heavy growth of whitish fungal colony (with PDI $=81$ to 100 ) (Figs. 3B, 4A and $\mathrm{B}$ ). The partially incompatible resistant reaction in $\mathrm{F}_{1}$ plants (with PDI = 21 to 40), could be distinguished visually from the completely incompatible or absolute resistant plants of RDV 29 (with PDI =0). The $\mathrm{F}_{1}$ plants were considered as 'partially resistant' for the purpose of testing of genetic ratio of test of goodness of fit. Disease severity rating had been widely distributed with PDI ranges of 0 to $100 \%$ in the $\mathrm{F}_{2}, 40$ to $100 \%$ in the susceptible backcross, and 0 to $40 \%$ in the resistant backcross population. In $\mathrm{F}_{2}$ population evaluated during rabi 2017-18, a total of 18 plants exhibited disease score of $0(\mathrm{PDI}=0)$ and categorized as 'highly resistant', 94 plants consisted of 'resistant'

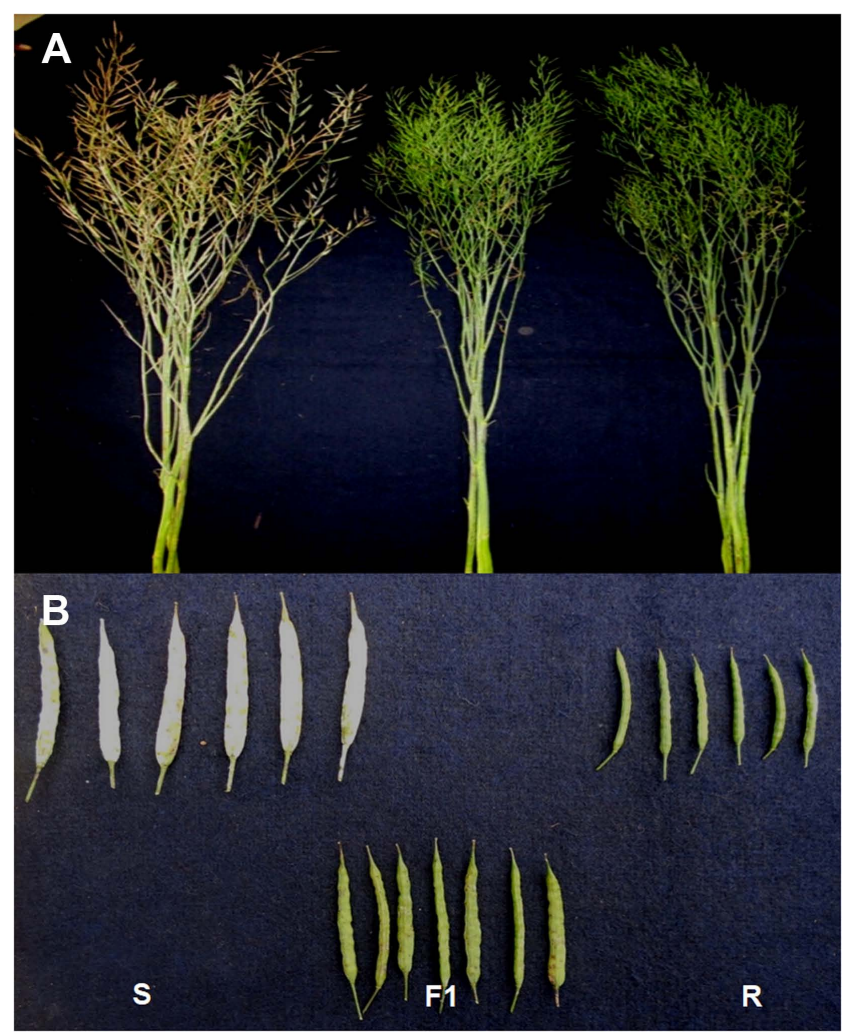

Fig. 4. Powdery mildew symptoms in parents (S, susceptible parent [RSEJ 775]; R, resistant parent [RDV 29]) and $F_{1}$. (A) On the whole plant. (B) On siliquae.

(with 1 score or PDI $=0$ to 20), 89 plants 'partially resistant' (with 2 score or PDI $=20$ to 40), 45 plants 'moderately susceptible' (with 3 score or PDI $=40$ to 60 ), 83 plants 'susceptible' (with 4 score or PDI $=60$ to 80 ) and 17 plants 'highly susceptible' (with 5 score or PDI $=80$ to 100 ). During kharif 2018, a total of 20 plants exhibited disease score of $0(\mathrm{PDI}=0)$ and categorized as 'highly resistant', 77 plants consisted of 'resistant' (with 1 score or PDI $=0$ to 20), 60 plants 'partially resistant' (with 2 score or PDI = 20 to 40), 39 plants 'moderately susceptible' (with 3 score or PDI $=40$ to 60), 76 plants 'susceptible' (with 4 score or PDI $=60$ to 80 ) and 17 plants 'highly susceptible' (with 5 score or PDI $=80$ to 100 ). In summary, the $F_{2}$ progeny plants segregated as highly resistant:resistant:partially resistant:moderately susceptible:susceptible:highly susceptible at the ratio of $1 / 4 / 4 / 2 / 4 / 1$, during both the seasons, i.e., rabi 2017-18 and kharif 2018 .

During rabi 2017-18, in susceptible back corss population $\left(\mathrm{F}_{1} \times \mathrm{RSEJ}\right.$ 775), a total of 9 plants exhibited disease score of 2 (PDI $=20$ to 40$)$ and categorized as 'partially resistant', 14 plants consisted of 'susceptible' (with 4 score or PDI $=60$ to 80 ) and 9 plants 'highly susceptible' (with 5 score or PDI $=80$ to 100$)$. Further, in resistant backcross $\left(F_{1}\right.$ 
$\times$ RDV 29), there were a total of 8 plants with disease score of $0(\mathrm{PDI}=0)$ categorized as 'higly resistant', 12 plants with 1 score or PDI $=0$ to 20 ('resistant') and 8 plants with 2 score or PDI $=20$ to 40 ('partially resistant'). During kharif 2018, out of 102 plants in susceptible back cross population 28 plants categorized as 'partially resistant', 53 plants consisted of 'susceptible' and 21 plants 'highly susceptible'. In resistant backcross, there were 45 'higly resistant', 103 'resistant', and 44 'partially resistant' plants. In summary, the susceptible back cross progeny plants segregated as partially resistant:susceptible:highly susceptible at the ratio of 1:2:1 and the resistant back cross progenies as highly resistant:resistant:partially resistant at the ratio of 1:2:1, during two seasons, i.e., rabi 2017-18 and kharif 2018. Distributions of disease severity ratings in $F_{2}$ made from reciprocal cross (RDV $29 \times$ RSEJ 775) evaluated during rabi 2017-18 mirror the distributions for the direct cross (RSEJ $775 \times$ RDV 29) (Table 3). In case of the reciprocal cross, the $F_{1}$ exhibited a PDI of $28.0 \%$, which was much like the $\mathrm{F}_{1}$ of direct cross.

\section{Discussion}

In the present study, we exploited the natural epiphytotic conditions available at Wellington and the genetic variability found among the Indian mustard germpalsm acceesions to identify resistant source against powdery mildew pathogen. The endemic form of powdery mildew in Indian mustard fields at Wellington is enabling us to undertake large scale field screening of germplasm/breeding materials every year. A significant variability for powdery mildew resistance/susceptibility among the 1,020 Indian mustard germplasm accesisons evaluated had been observed and the most important outcome was the identification of 12 accessions which are partially resistant and one accession RDV 29 with high degree of resistance consistently against the $E$. cruciferarum. This resistant genotype will prove to be the stepping stone for initiating a systematic breeding program to develop powdery mildew-resistant Indian mustard varieties in future. Similarly, considerable extent of variability among Indian mustard germplasm accessions for resistance to other important diseases viz. downney mildew, white rust, Alternaria leaf blight and Sclerotinia stem rot (Bisht et al., 2015) and white rust (Yadav et al., 2018) had been reported from evaluation of large number of germplasm accessions under natural disease hot spot conditions. In India, earlier attempts to find resistant source to powdery mildew of Indian mustard did not succeed as all the B. juncea genotypes evaluated were found to be highly susceptible (Kumar et al., 2002; Mohitkar et al., 2012; Narain and Sid- diqui, 1965). The loss in seed yield due to this pathogen is expected to increase in near future because of the unpredictable changes in climatic conditions. The warm and drier climatic conditions under which the mustard is being grown in India especially in zone IV (which covers mustard growing areas in the states of Gujarat, Maharashtra and Rajasthan) is very conducive for the outbreak of powdery mildew in epiphytotic form. Therefore, it is essential to develop powdery mildew resistance varieties by employing RDV 29 as donor in hybridization programme.

In previous studies, different phenotypic classes [4 classes in A. thaliana (Adam and Somerville, 1996), 5 classes in Indian mustard (Kumar and Saharan, 2002; Mehta et al., 2005), and 5 classes in B. napus (Alkooranee et al., 2015)] were used to measure the severity of powdery mildew pathogen and for carrying out the genetic analysis of resistance. All these studies took into account the percentage of infection on leaves only whereas, in the present study owing to the wide range of disease reaction phenotypes observed in $\mathrm{F}_{2}$ population, for the first time we developed a more descriptive classification system using six scales $(0$, $1,2,3,4$, and 5), taking into account the progressive spread of the disease into different plant parts viz., leaves, stem, primary and secondary branches and siliquae of the host (Table 2). This disease scoring scale was developed on the basis of 'extent of pathogen growth' parameter. Adam and Somerville (1996) also reported that the parameter 'extent of pathogen growth' was more stable than the parameter 'host necrosis/chlorosis' while scoring the powdery mildew disease. The newly developed disease scoring system based on six scales can widely be applied in future for large scale evaluation of gremplasm resources and breeding materials for powdery mildew resistance.

Observation of $F_{1}$ progeny inferred that resistance trait is semi-dominant in nature. In $\mathrm{F}_{2}$, we classified the individual plants into six classes as mentioned in Table 3 to perform a discreet analysis wherein a 9:6:1 (resistant:susceptible:highly susceptible) model is proposed to explain the data. The closely related nearby phenotypic classes are grouped together to fit to $9: 6: 1$ (resistant:susceptible:highly susceptible) ratio in $\mathrm{F}_{2}, 1: 2: 1$ (partially resistant:susceptible:highly susceptible) ratio in susceptible backcross and all 'resistant' phenotype in resistant backcross. These segregation ratios in $F_{2}$ and back cross populations, in conjunction with the $F_{1}$ phenotype, suggested that resistance to E. cruciferarum is determined by two unlinked loci in RDV 29 with partially dominant resistant alleles at both the loci. Also, the expression of the resistance is sensitive to gene dosage in the accession RDV 29. With a model of two independent, semi-dominant 
Table 4. Assigned gene symbols for parents, $F_{1}, F_{2}$, and back cross progenies

\begin{tabular}{|c|c|c|c|}
\hline Generation & Genotype & Genotypic ratio & Phenotype \\
\hline RSEJ 775 (susceptible parent) & aabb & - & Highly susceptible \\
\hline RDV 29 (resistant parent) & $\mathrm{AABB}$ & - & Highly resistant \\
\hline $\mathrm{F}_{1}($ RSEJ $775 \times$ RDV 29) & $\mathrm{AaBb}$ & - & Partially resistant \\
\hline \multirow[t]{6}{*}{$\mathrm{F}_{2}$} & AABB & $1 / 16$ & Highly resistant \\
\hline & $\mathrm{AaBB}, \mathrm{AABb}$ & $4 / 16$ & Resistant \\
\hline & $\mathrm{AaBb}$ & $4 / 16$ & Partially resistant \\
\hline & $\mathrm{AAbb}, \mathrm{aaBB}$ & $2 / 16$ & Moderately susceptible \\
\hline & Aabb, aaBb & $4 / 16$ & Susceptible \\
\hline & aabb & $1 / 16$ & Highly susceptible \\
\hline \multirow[t]{3}{*}{$\mathrm{BC}_{1} \mathrm{P}_{1}\left(\mathrm{~F}_{1} \times \mathrm{RSEJ} 775\right)$} & $\mathrm{AaBb}$ & $1 / 4$ & Partially resistant \\
\hline & Aabb, aaBb & $2 / 4$ & Susceptible \\
\hline & aabb & $1 / 4$ & Highly susceptible \\
\hline \multirow[t]{3}{*}{$\mathrm{BC}_{1} \mathrm{P}_{2}\left(\mathrm{~F}_{1} \times \mathrm{RDV} 29\right)$} & $\mathrm{AABB}$ & $1 / 4$ & Highly resistant \\
\hline & $\mathrm{AABb}, \mathrm{AaBB}$ & $2 / 4$ & Resistant \\
\hline & $\mathrm{AaBb}$ & $1 / 4$ & Partially resistant \\
\hline
\end{tabular}

genes controlling resistance, there would be an expectation for $1 / 4$ 'partially resistant', $1 / 2$ 'susceptible', and 1/4 'highly susceptible' individuals among the progenies of susceptible backcross $\left(F_{1} \times\right.$ RSEJ 775$)$ which is proved in this study (Table 3). Distribution of disease severity ratings in $F_{1}$ and $\mathrm{F}_{2}$ populations made from reciprocal cross (RDV $29 \times$ RSEJ 775) mirror the distribution for the direct cross (RSEJ $775 \times$ RDV 29) (Table 3) and reconfirmed the involvement of two genes with semi-dominant and gene dosage effect in the inheritance of powdery mildew resistance in Indian mustard. In similar studies, Adam and Somerville (1996) reported that out of the six A.thaliana accesions they evaluated, resistance was conferred by single locus in five accessions, and two unlinked loci in one accession. In four accessions, powdery mildew resistance was encoded by a semi-dominant allele. However, susceptibility was dominant to resistance in two accessions. Xiao et al. (2001) reported that $A$. thaliana locus resistance to powdery mildew $(R P W 8)$ contains two naturally polymorphic, dominant $\mathrm{R}$ genes, $R P W 8.1, R P W 8.2$, which individually control resistance to a broad range of powdery mildew pathogens. Several other studies had also examined the RPW8 loci in detail (Li et al., 2016; Xiao et al., 1997, 2004) and reported that there were four homologs to RPW8s $(B r H R s)$ in $B$. rapa, three in B. oleracea (BoHRs) and seven in B. naphus $(B n H R \mathrm{~s})$. One transgenic study also reported that BnHRs are functional to trigger cell death and activate resistance to powdery mildew. Thus, polymorphic $R P W 8$ locus defines a major source of resistance to powdery mildew disease in A. thaliana. Similar kind of molecular analysis is required in B. juncea accession RDV 29 to find out degree of ho- mology to the already reported resistant alleles in other related species.

The phenotypic classes along with their gene symbols are listed in Table 4. In this model, the parents seem to differ at two-gene loci, each with two alleles. Complete resistance can be achieved by the complementary (additive) action of four partially dominant alleles. We assumed that progeny with intermediate phenotypes such as 'resistance', 'partially resistance', 'moderately susteptible', and 'susceptible' were carrying 3 dominant alleles at two loci, 2 dominant alleles at two loci, 2 dominant alleles at one locus and one dominant allele at one locus, respectively as shown in Table 4. The genotype AaBb with two dominant alleles for both the genes is classified as 'partially dominant' whereas, the genotypes aaBB and AAbb with two dominant alleles for same gene were classified as 'moderately susceptible'.

It is imminent as the present study did not find example of complex, multigenomic inheritance, instead, the inheritance of powdery mildew resistance followed a two-gene simple Mendelian pattern in the accession RDV 29. Identification of a completely resistant source for powdery mildew of Indian mustard and information on its inheritance pattern is expected to aid the Indian mustard breeding by the ways of mapping, characterization of powdery mildew resistance genes and their transfer into improved agronomical background.

\section{Acknowledgments}

The authors are highly thankful to the Head, ICAR-Indian Agricultural Research Institute, Regional Station, Welling- 
ton, The Nilgiris, Tamil Nadu, India, for resource facilitation.

\section{References}

Adam, L. and Somerville, S. C. 1996. Genetic characterization of five powdery mildew disease resistance loci in Arabidopsis thaliana. Plant J. 9:341-356.

Alkooranee, J. T., Yin, Y., Aledan, T. R., Jiang, Y., Lu, G., Wu, J. and $\mathrm{Li}, \mathrm{M}$. 2015. Systemic resistance to powdery mildew in Brassica napus (AACC) and Raphanus alboglabra (RRCC) by Trichoderma harzianum TH12. PLoS ONE 10:e0142177.

Annonymous. 2015. Vision 2050. ICAR-Directorate of Rapeseed Mustard Research. URL http://www.drmr.res.in [10 December 2019].

Bisht, K. S., Rana, M., Gairola, K., Sharma, B. C., Tewari, A. K. and Awasthi, R. P. 2015. Screening of Brassica germplasm for resistance to major diseases of rapeseed-mustard. Bioscan 10:2111-2119.

Dange, S. R. S., Patel, R. L., Patel, S. I. and Patel, K. K. 2002. Assessment of losses in yield due to powdery mildew disease in mustard under North Gujarat conditions. J. Mycol. Plant Pathol. 32:249-250.

Kanzaria, K. K. 2012. Management of powdery mildew disease (Erysiphe cruciferarum Opiz ex. Junell.) of mustard [Brassica juncea (L.) Czern. \& Coss]. M.Sc. thesis. Junagadh Agricultural University, Junagadh, Gujarat, India.

Kaur, P., Li, C. X., Barbetti, M. J., You, M. P., Li, H. and Sivasithamparam, K. 2008. First report of powdery mildew caused by Erysiphe cruciferarum on Brassica juncea in Australia. Plant Dis. 92:650.

Kim, J. Y., Kim, B. S., Cho, S. E. and Shin, H. D. 2013. First report of powdery mildew caused by Erysiphe cruciferarum on Indian mustard (Brassica juncea) in Korea. Plant Dis. 97:1383.

Kumar, S. and Saharan, G. S. 2002. Sources of multiple disease resistance in Brassica spp. J. Mycol. Plant Pathol. 32:184188.

Kumar, S., Saharan, G. S. and Singh, D. 2002. Inheritance of resistance in inter and intraspecific crosses of Brassica juncea and Brassica carinata to Albugo candida and Erysiphe cruciferarum. J. Mycol. Plant Pathol. 32:59-63.

Li, Q., Li, J., Sun, J.-L., Ma, X.-F., Wang, T.-T., Berkey, R., Yang, H., Niu, Y.-Z., Fan, J., Li, Y., Xiao, S. and Wang, W.-M. 2016. Multiple evolutionary events involved in maintaining homologs of Resistance to Powdery Mildew 8 in Brassica napus. Front. Plant Sci. 7:1065.

Meena, P. D., Rathi, A. S., Kumar, V. and Singh, D. 2014. Compendium of rapeseed-mustard diseases: identification and management. ICAR-Directorate of Rapeseed-Mustard Research, Bharatpur, India. $30 \mathrm{pp}$.
Mehta, S., Sangwan, M. S. and Saharan, G. S. 2005. Fungal diseases of rapeseed-mustard. In: Diseases of oilseed crops, eds. by G. S. Saharan, N. Mehta and M. S. Sangwan, pp. 15-86. Indus Publishing Company, New Delhi, India.

Ministry of Agriculture and Farmers Welfare, Government of India. 2017. Pocket book of agricultural statistics. Directorate of Economics and Statistics, Department of Agriculture, Cooperation and Farmers Welfare, Ministry of Agriculture and Farmers Welfare, Government of India, New Delhi, India. $194 \mathrm{pp}$.

Mohitkar, S. A., Mate, G. D. and Pillai, T. 2012. Screening of mustard varieties against powdery mildew caused by Erysiphe cruciferarum. In: 3rd Global Conference - Plant Pathology for Food Security, eds. by Indian Society of Mycology and Plant Pathology at Maharana Pratap University of Agriculture and Technology, pp. 1-224. Udaipur, Rajasthan, India.

Nanjundan, J., Manjunatha, C., Berliner, J., Jayaprakash, P., Vikas, V. K., Nallathambi, P., Umamaheshwari, C. and Sivasamy, M. 2017. Sequential infection of three biotrophic fungal pathogens (Albugo candida, Peronospora parasitica and Erysiphe cruciferarum) in Indian mustard at Wellington. Nilgiri Wheat News 8:13-14.

Narain, A. and Siddiqui, J. A. 1965. Field reaction of species of Brassica to Erysiphe polygoni. Indian Oilseeds J. 9:153-157.

Saharan, G. S. and Kaushik, J. C. 1981. Occurrence and epidemiology of powdery mildew of Brassica. Indian Phytopathol. 34:54-57.

Snedecor, G. W. and Cochran, W. G. 1967. Statistical methods. 6th ed. Iowa State University Press, Ames, IA, USA. 593 pp.

Tam, L. T. T., Dung, P. N. and Liem, N. V. 2016. First report of powdery mildew caused by Erysiphe cruciferarum on Brassica juncea in Vietnam. Plant Dis. 100:856.

Wheeler, B. E. J. 1969. An introduction to plant diseases. John Wiley and Sons Ltd., London, UK. 254 pp.

Xiao, S., Ellwood, S., Calis, O., Patrick, E., Li, T., Coleman, M. and Turner, J. G. 2001. Broad-spectrum mildew resistance in Arabidopsis thaliana mediated by RPW8. Science 29:118120.

Xiao, S., Ellwood, S., Findlay, K., Oliver, R. P. and Turner, J. G. 1997. Characterization of three loci controlling resistance of Arabidopsis thaliana accession Ms-0 to two powdery mildew diseases. Plant J. 12:757-768.

Xiao, S., Emerson, B., Ratanasut, K., Patrick, E., O’Neill, C., Bancroft, I. and Turner, J. G. 2004. Origin and maintenance of a broad-spectrum disease resistance locus in Arabidopsis. Mol. Biol. Evol. 21:1661-1672.

Yadav, R., Prasad, L., Nanjundan, J., Tewari, A. K., Singh, P., Sandhu, P. S., Pant, U., Avtar, R., Radhamani, J., Rao, S. K. M. and Rana, J. C. 2018. Identification and evaluation of Indian mustard genotypes for white rust resistance and agronomic performance. Indian J. Genet. 78:81-89. 